\title{
The Impact of Youth Policy Measures on the Labour Market
}

\author{
Laima Okunevičiūtè Neverauskienè $\dot{1}^{1,2}$, Jolanta Sakalauskiené2 \\ ${ }^{1}$ Business Management Faculty, Vilnius Gediminas Technical University, Vilnius, Lithuania \\ ${ }^{2}$ Lithuanian Social Research Centre, Vilnius, Lithuania \\ E-mails: ${ }^{1}$ Laima.Okuneviciute.Neverauskiene@vgtu.lt (corresponding author); ${ }^{2}$ institutas@dsti.lt
}

Received 28 February 2017; accepted 07 April 2017

\begin{abstract}
Our modern society that is based on innovation is ever more quickly developing. Further and further more, one policy measures and actions are not sufficient in ones ability to solve emerging problems and the resulting challenges. Modern solutions require an inter-sectoral approach and coordination of different policy actors and systematic action. The aim of this article is to show the impact of youth policy as a separate policy area on employment policy, specifically in the Lithuanian labor market. The article focuses on the category of 15-29 year-old inactive youth. The article analyzes individual specific measures of youth policy which affect young people's ability to integrate and reintegrate into the labor market, best practices from different European Union countries are revised too. The article aims to have an inter-sectoral lens in its outlook and methodology. Inter-sectoral interaction should be perceived as the most effective element in its ability to solve labor market problems of this particular case; particularly through the integration of youth policy measures and the employment policy field. The article analyzes the Lithuanian situation beginning with the start of the Youth Guarantee initiative in Lithuania. The final section of the article identifies conclusions and provides recommendations.
\end{abstract}

Keywords: youth policy, youth guarantees initiative, labor market, youth work, young people in a NEET situation, cross-sectorial cooperation.

JEL Classification: 015, J21, J23, J42, J48, J68, I25, Z18.

Conference topic: Sustainable Economics Development.

\section{Introduction}

Young people are an integral part of the global society; heavily affected by many different processes that arise from globalization. For a young person to get recognition and status from society he/she must answer many different questions, such as: how do I become independent? How do I find my identity? How do I choose the right profession? How can I use technology further integration into society?

Contemporary society requires one to possess efficiency, speed and adaptability. Such requirements are a must not only for individuals, but also for political tools and systems that enable them to function in accordance to modern societal needs. Changing generations (X, Y, Z) require new approaches and reforms that must appear naturally in order to meet the needs arising from change. One can see that political systems that are most affected by this change arise from employment and education policy areas. These policy areas are heavily interlinked with personal development and personal growth. They specifically affect a given person's ability to successfully integrate into society and the labor market. Different policy measures arising from education and employment policy areas that are symbiotic, work hand in hand and are strategically crafted are a positive addition to society's success. Further on, they supplement the growth of the gross domestic product (hereinafter - GDP), one of the indicators of economic success.

Young people, as a specific group are open to change and innovation. However, certain conditions such as; loss of a guardian, disability, poverty and other social issues can hinder their access to employment and education. Such obstructions results into a lack of successful integration and participation within the wider society. One such group that suffers from various obstructions can be identified as NEET, i.e. a young people not in education, employment or training (hereinafter - young people in a NEET situation). Young people in a NEET situation can encounter many different societal problems such as isolation, lack of independence, poor mental health and peer pressure, further interlocking them in a vicious circle that keeps them away from successful integration into society in the future.

Social exclusion within youth and especially within young people in a NEET situation can obstruct economic growth and cause further expenses to Europe. As it is mentioned in Eurofund report expenses for young people in a

C 2017 L. Okunevičiūtė Neverauskienè, J. Sakalauskienè. Published by VGTU Press. This is an open-access article distributed under the terms of the Creative Commons Attribution (CC BY 4.0) License, which permits unrestricted use, distribution, and reproduction in any medium, provided the original author and source are credited. 
NEET situation in whole EU in 2014, have reached 162 billion euros. The estimated number equals to 1.26\% of EU's GDP, an increase of almost 10 bilion euros in comparison with 2011 (European Foundation for the Improvement ... 2016a). Due to such a negative effect on national governments and the whole of the EU budget, all member states must thoroughly commit to resolving these grave issues. Different policy actions must be coordinated as a response; especially in employment, education and training areas in order to assure societal inclusion of young people in a NEET situation. One of the most effective ways to tackle this issue comes from constructive cooperation of different interest groups and policy sectors. Finally, different programs, measures and action plans must be compatible and strengthened by comprehensive cooperation.

\section{Situation of the youth in the Lithuanian labour market comparing the EU context}

The behaviour of young people in the labour market and the reasons behind their unemployment depend on many social, economic and demographic factors that are very much interrelated. Scientific literature and research review allows separating the existence of two basic views about causes of high youth joblessness. According to the demand view, the principal reason for high and increased joblessness is the lack of adequate demand for youth workers due such factors as slow economic growth, cyclical weaknesses in the economy, changes in the mix jobs which alter the level of demand, and effects of minimum wages on employment dynamics (Baranowska, Gebel 2010; Cuesta et al. 2011; Christopoulou 2013; Junankar 2015). According to the supply view, the principal reason for high and increased youth joblessness is a lack of skills, incentives and/or aspirations on the part of young (Korpysa 2010; Graham et al. 2014; Turek 2015; Cunningham, Villasenor 2016; Hallsten et al. 2017).

According to the data provided by Eurostat in 2016, the worst situation is in the southern European Union countries, youth unemployment rate is above $40 \%$ (in Greece, Spain, Italy). The lowest youth unemployment rate was observed in Netherlands $(11.3 \%)$, Austria $(10.6 \%)$, Malta $(11,8 \%)$. At the same time it should be noted that youth unemploymend rate decreased significantly since the year 2011-2012 in the Baltic countries and lately it is below the EU average (in 2015 percentage respectively ranged from 13.1\% (Estonia), up to 16.3\% (Lithuania and Latvia) (Fig. 1).

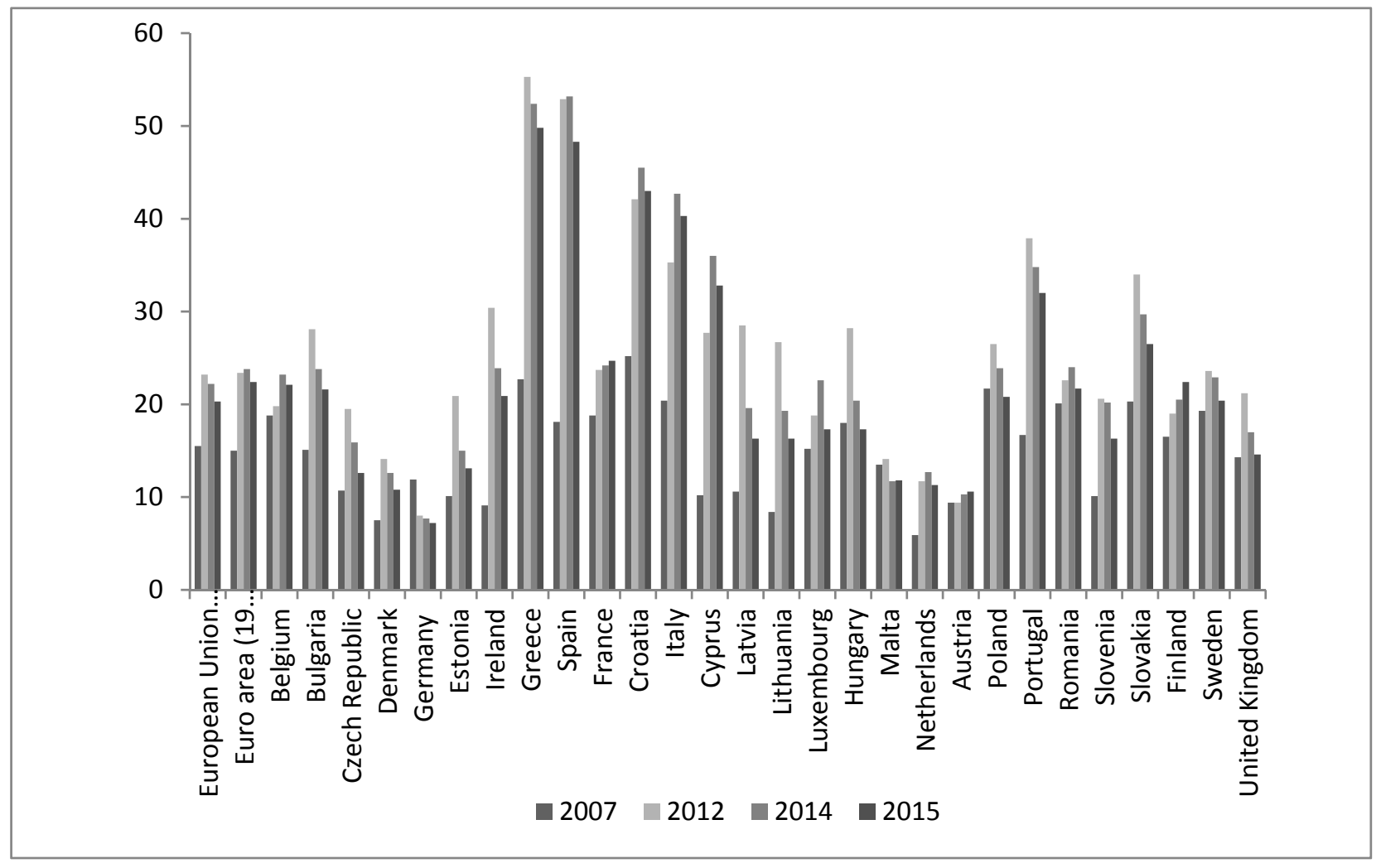

Fig. 1. Youth unemployment rate in EU (\%) (Source: compiled by author's based on Eurostat data)

Traditionally, youth unemployment is higher than adult unemployment in almost every country and this is the case whether total unemployment in a country is high or low. Statistical analysis done by the Lithuanian Department of Statistics (Statistics Lithuania) shows, that youth unemployment rate remains significantly higher compared to other age groups in Lithuania (Table 1). 
Table 1. Unemployment rate by age and sex in Lithuania (\%) (Source: Statistics Lithuania database 2017)

\begin{tabular}{c|c|c|c|c|c|c|c|c}
\hline Sex & Year & Total by age & $15-24$ & $15-64$ & $15-74$ & $20-64$ & $25-54$ & $55-64$ \\
\hline \multirow{5}{*}{ Males and Females } & 2012 & 13.4 & 26.7 & 13.6 & 13.4 & 13.5 & 12.6 & 11.9 \\
& 2013 & 11.8 & 21.9 & 12.0 & 11.8 & 11.9 & 11.0 & 11.2 \\
& 2014 & 10.7 & 19.3 & 10.9 & 10.7 & 10.8 & 9.9 & 10.7 \\
& 2015 & 9.1 & 16.3 & 9.3 & 9.1 & 9.2 & 8.6 & 8.7 \\
& 2016 & 7.9 & $\ldots$ & $\ldots$ & $\ldots$ & $\ldots$ & $\ldots$ & $\ldots$ \\
\hline \multirow{5}{*}{ Males } & 2012 & 15.2 & 29.7 & 15.5 & 15.2 & 15.3 & 14.1 & 13.5 \\
& 2013 & 13.1 & 23.0 & 13.4 & 13.1 & 13.2 & 11.9 & 13.9 \\
& 2014 & 12.2 & 19.6 & 12.4 & 12.2 & 12.3 & 11.1 & 13.8 \\
& 2015 & 10.1 & 16.0 & 10.3 & 10.1 & 10.2 & 9.5 & 10.6 \\
& 2016 & 9.1 & $\ldots$ & $\ldots$ & $\ldots$ & $\ldots$ & $\ldots$ & $\ldots$ \\
\hline \multirow{5}{*}{ Females } & 2012 & 11.6 & 22.7 & 11.8 & 11.6 & 11.7 & 11.1 & 10.5 \\
& 2013 & 10.5 & 20.4 & 10.6 & 10.5 & 10.6 & 10.1 & 8.7 \\
& 2014 & 9.2 & 18.7 & 9.4 & 9.2 & 9.3 & 8.8 & 7.9 \\
& 2015 & 8.2 & 16.6 & 8.4 & 8.2 & 8.3 & 7.8 & 7.1 \\
\end{tabular}

Particularly important and relevant retain their NEET problem, which has recently received considerable attention in Europe.The NEET rate was 11.8\% (10.7\% males and 13.0\% females) in Lithuania in 2015 (Table 2).

Table 2. Young people (15-29) neither in employment nor in education and training (\%) (Source: Eurostat data)

\begin{tabular}{|c|c|c|c|c|c|c|c|c|c|}
\hline & 2007 & 2008 & 2009 & 2010 & 2011 & 2012 & 2013 & 2014 & 2015 \\
\hline European Union (28 countries) & 13.2 & 13.1 & 14.7 & 15.2 & 15.4 & 15.8 & 15.9 & 15.4 & 14.8 \\
\hline Euro area (19 countries) & 13.0 & 13.2 & 15.0 & 15.3 & 15.3 & 15.9 & 16.0 & 15.7 & 15.2 \\
\hline Belgium & 13.0 & 12.0 & 12.8 & 13.0 & 13.8 & 14.4 & 14.9 & 14.1 & 14.4 \\
\hline Bulgaria & 20.3 & 18.5 & 20.8 & 23.5 & 24.7 & 24.7 & 25.7 & 24.0 & 22.2 \\
\hline Czech Republic & 11.6 & 10.7 & 12.7 & 12.9 & 12.1 & 12.9 & 12.8 & 12.1 & 11.8 \\
\hline Denmark & 5.3 & 5.0 & 6.5 & 7.3 & 7.6 & 8.2 & 7.5 & 7.3 & 7.7 \\
\hline Germany & 11.6 & 11.0 & 11.4 & 10.8 & 9.7 & 9.3 & 8.7 & 8.7 & 8.5 \\
\hline Estonia & 11.6 & 11.4 & 18.3 & 18.1 & 14.7 & 15.1 & 14.3 & 13.8 & 12.5 \\
\hline Ireland & 11.9 & 16.2 & 20.3 & 21.5 & 22.0 & 21.3 & 18.6 & 18.1 & 16.8 \\
\hline Greece & 15.2 & 14.8 & 15.9 & 18.6 & 23.0 & 26.8 & 28.5 & 26.7 & 24.1 \\
\hline Spain & 12.8 & 15.3 & 19.9 & 20.0 & 20.6 & 22.2 & 22.5 & 20.7 & 19.4 \\
\hline France & 12.8 & 12.6 & 14.7 & 14.8 & 14.7 & 15.1 & 13.8 & 14.2 & 14.7 \\
\hline Croatia & 14.5 & 13.0 & 14.9 & 17.6 & 19.1 & 19.7 & 22.3 & 21.8 & 20.1 \\
\hline Italy & 18.8 & 19.3 & 20.5 & 22.0 & 22.5 & 23.8 & 26.0 & 26.2 & 25.7 \\
\hline Cyprus & 10.3 & 10.9 & 11.5 & 12.9 & 14.8 & 17.3 & 20.4 & 19.5 & 18.5 \\
\hline Latvia & 13.9 & 13.6 & 20.8 & 20.7 & 19.1 & 17.2 & 15.6 & 15.2 & 13.8 \\
\hline Lithuania & 10.1 & 11.9 & 15.0 & 17.0 & 14.7 & 13.9 & 13.7 & 12.9 & 11.8 \\
\hline Luxembourg & 7.3 & 9.2 & 7.5 & 6.1 & 6.6 & 7.6 & 7.2 & 6.5 & 7.6 \\
\hline Hungary & 15.7 & 15.9 & 17.9 & 17.7 & 17.6 & 18.7 & 18.4 & 16.4 & 15.1 \\
\hline Malta & 13.7 & 11.4 & 12.6 & 12.2 & 12.1 & 11.7 & 11.3 & 11.7 & 11.4 \\
\hline Netherlands & 4.9 & 4.6 & 5.3 & 5.7 & 5.9 & 6.5 & 7.5 & 7.6 & 6.7 \\
\hline Austria & 9.4 & 8.9 & 9.6 & 9.1 & 8.5 & 8.2 & 8.6 & 9.3 & 8.7 \\
\hline Poland & 14.4 & 12.7 & 14.0 & 14.8 & 15.2 & 15.7 & 16.2 & 15.5 & 14.6 \\
\hline Portugal & 12.7 & 11.9 & 12.5 & 13.6 & 13.9 & 15.6 & 16.4 & 14.6 & 13.2 \\
\hline Romania & 14.8 & 13.2 & 15.7 & 18.9 & 19.5 & 19.3 & 19.6 & 19.9 & 20.9 \\
\hline
\end{tabular}


Continued Table 2

\begin{tabular}{l|c|c|c|c|c|c|c|c|c}
\hline & 2007 & 2008 & 2009 & 2010 & 2011 & 2012 & 2013 & 2014 & 2015 \\
\hline Slovenia & 8.2 & 7.5 & 9.3 & 9.4 & 9.4 & 11.8 & 12.9 & 12.9 & 12.3 \\
Slovakia & 16.9 & 15.3 & 17.3 & 19.0 & 18.7 & 18.8 & 19.0 & 18.2 & 17.2 \\
Finland & 8.4 & 8.9 & 11.3 & 10.5 & 10.0 & 10.4 & 10.9 & 11.8 & 12.4 \\
Sweden & 7.9 & 8.0 & 9.9 & 8.3 & 7.9 & 8.4 & 7.9 & 7.8 & 7.4 \\
United Kingdom & 12.9 & 13.1 & 14.4 & 14.6 & 15.4 & 15.3 & 14.6 & 13.4 & 12.7 \\
\hline
\end{tabular}

\section{Youth policy - a holistic and inter-sectoral approach}

Lithuanian youth policy, as a universally recognized policy area has been around for more than twenty years. Its legality arises from the Youth Policy Framework Act No. IX-1871, was adopted in 2003 (Official Gazette 2003, No. 119-5406). Within the act, youth policy is defined as direct set of actions with which youth problems are addressed. It is intended to create favorable conditions for young people to form their personality, facilitate their integration and further understanding and tolerance between youth and society. The legal act defines youth as 14-29 year olds and intends to solve the issues and challenges those individuals face (TAR 2016-11-17, i. k. 2016-26979).

Lithuanian youth policy is implemented in international treaties, laws and other legislation in these key areas: citizenship and military service, education, training, science, research and education, non-formal education, labor and employment, housing, leisure, recreation, art and culture, social, health, physical education and sports, drug addiction and other forms of addiction prevention, crime prevention and other areas identified in further laws and regulations. Youth policy is horizontal and aimed towards its target group. Thus, it has been difficult to accurately identify the added value of youth policy and its impact on other policy areas. In many cases, youth policy and its instruments were viewed only as an auxiliary policy branch which contributes to motivation of young people and their sustainable integration into social life. Even while youth policy provides clearly visible added value such as informally acquired competences which facilitate integration into active social life; it was not formally recognized.

In many cases, youth involvement in youth work organizations and NGO's was seen as meaningful, safe and well-spent leisure time - a preventative mechanism. However, youth policy was not assessed and appreciated as a field that has effect on employment, integration or national security. However, one can suggest that youth policy, as a policy area is holistic and inter-sectoral, i.e. it helps in finding solutions in other policy areas. Cross-sectoral collaboration and policy effectiveness depends on the level of coordination. If coordination happens in advance, and actors from two different policy areas work at the same time; cooperation tends to be more fruitful. Nonetheless, if cooperation happens after a given policy area has its actions already planned and the other is only invited to contribute and assist effectiveness might plummet. Such cooperation usually is aimed at consequence management and not at fighting the root causes of the issue. In order to have successful inter-sectoral cooperation, one must consider the fact that not only different action areas must be coordinated, but also that budget consolidation must be implemented. Such implementation ensures that resources are used effectively and are not duplicated.

The main youth policy instrument and tool is youth work which in Lithuania and the EU is understood as a set of actions directed toward young people regarding activities where they are taken voluntarily, designed for supporting their personal and social development through non-formal and informal learning. Youth work is a broad term covering a broad scope of activities of a social, cultural, educational or political nature by, with and for young people. Increasingly, such activities also include sport and services for young people. Youth work belongs to the area of 'out-ofschool' education, as well as specific leisure time activities managed by professional or voluntary youth workers and youth leaders. It is delivered in different forms and settings (e.g. open-access, group-based, programme-based, outreach and detached). Youth work focuses on the personal and social development of young people and has an extended reach which accesses and engages young people based on their needs and interests and takes account of their environment. Youth work plays an important role in preventing social exclusion and enhancing social inclusion. Social inclusion requires a comprehensive and cross-sectoral approach to address the multi-faceted nature of marginalisation and exclusion in society (European Commission 2015a; European Commission Report 2014). Other popular tool in youth policy area is volunteering is generally considered an altruistic activity where an individual or group provides services for no financial gain "to benefit another person, group or organization". Volunteering is also renowned for skill development and is often intended to promote goodness or to improve human quality of life. Volunteering may have positive benefits for the volunteer as well as for the person or community served.

\section{Young people in a NEET situation as a target group, its specifics and problems}

In 2010, the European Commission presented young people in a NEET situation as important target group in the field of youth, at the same time they provided indicators and the methodology of young people's in a NEET situation calculations (European Commision 2010a). The formation of a young people in a NEET situation indicator" is as a very 
good way to observe and accurately calculate the actual youth unemployment number. Young people in a NEET situation group is not homogeneous; it involves many different young people that are diverse in their level of education, demographics and social-economic status. For example; a young person in a NEET situation can be someone that has only secondary education and no work experience while at the same time, a young person in a NEET situation can be someone that is highly educated, 28 years old and unemployed. Naturally, such heterogeneity requires different policy measures which can be correctly selected only if group structure and reasons for its formation are clearly understood. The heterogeneity of young person in a NEET situation group primarily arises due to the differences of "when and why" a young person becomes part of this group. As seen in Figure 2 below, a young person can experience many different obstacles in critical moments of his or hers life when seeking employment that can lead him or her to become a young person in a NEET situation. A young person's road towards employment can be divided into three different parts:

1) Participation in the education system and possible dropping out

2) The transition from education to the labor market

3) Keeping up employment long term (European Foundation for the Improvement ... 2012a; European Foundation for the Improvement ... 2014).

Problems of a young person in a NEET situation individual coincide and depend on the stage that a young person falls-out out of the system. In order to solve the problems essentially cross-sectorial approach and multi-organizational governance is needed (Tosun 2017).

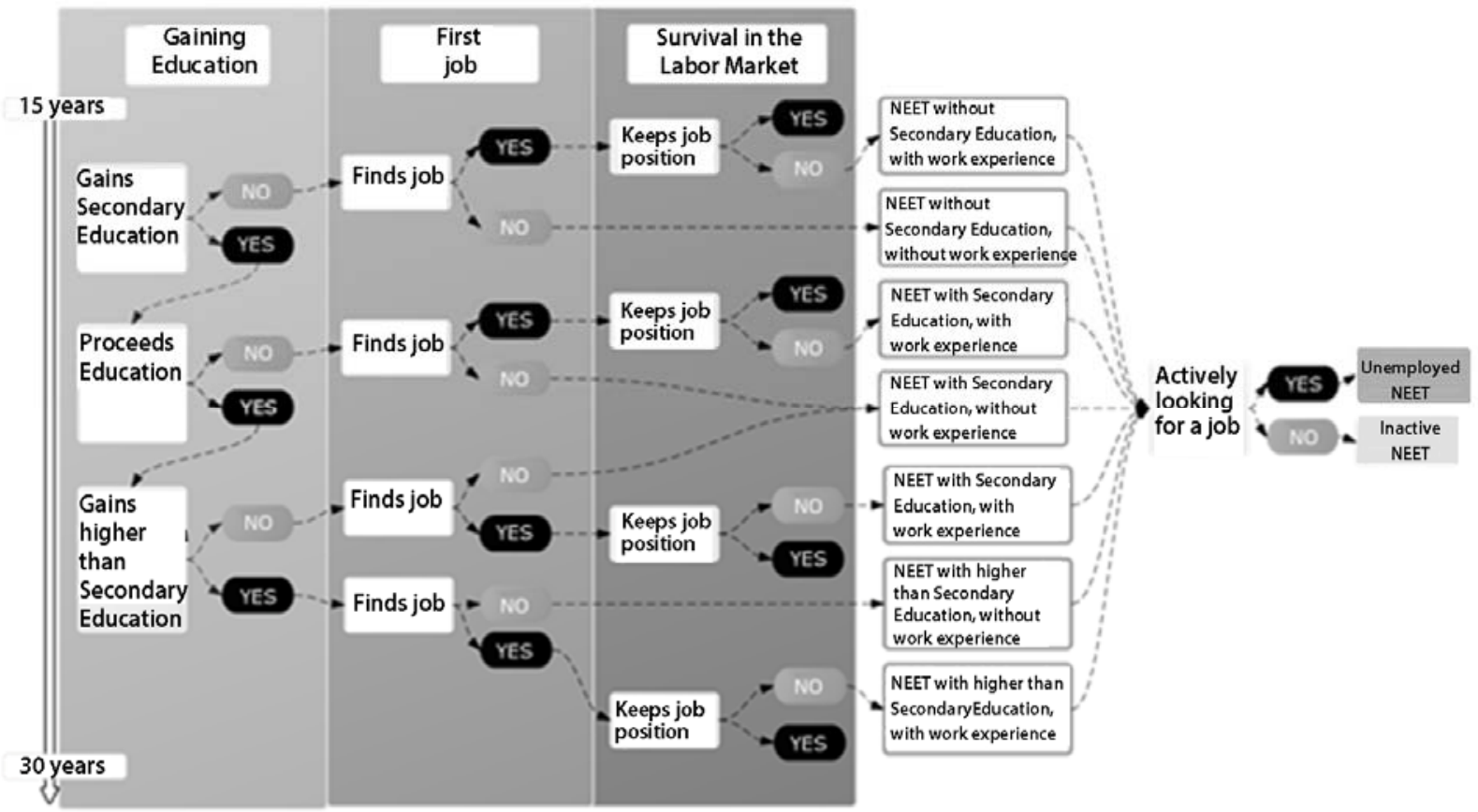

Fig. 2. Possible way, how young person can become a NEET

Young people in a NEET situation tend to have very different reasons or problems that cause them not to participate in the labor market, education or training. Within inactive youth there are four different groups with different needs (European Foundation for the Improvement ... 2012b).

Unavailable. This group is formed by individuals that have family or nursing obligations, health issues and or are disabled.

Disengaged. Young people that are not limited by additional obligations, sick or disabled but that are not actively looking for a job or education. This group is made up of unmotivated, asocial youths as well as youths that have chosen a dangerous lifestyle.

Opportunity-seekers. Young people that actively seek work or training opportunities, but fail to find appropriate proposals, which they would consider to match their skills and status.

Volunteers. Young people who have chosen to voluntarily belong to category. This group includes young travelers, artists, musicians and participants in voluntary training or other similar activities.

In the second half of 2013, the EU Council was chaired by Lithuania. At this time the "Young people's in a NEET situation" problem and social integration issues were chosen as a national priority of the country during whole Presidency period. Before this time, work with young people in a NEET situation was not actively discussed nationally. Most of the measures were directed towards youth in general, their social integration, promotion of volunteering and 
participation in NGO's. However, direct, planned and systemic work with young people in a NEET situation started when Lithuania started implementing the youth guarantee scheme. It's important to mention that during the Presidency Lithuania have also prepared Council Conclusion on enhancing the social inclusion of young people not in employment, education or training (Council Conlusions 2013b).

\section{Working with NEET youth system and the implementation of the Youth Guarantee initiative in Lithuania}

2010 marked the launch of the European Union's ten-year jobs and growth strategy "Europe 2020". One of the main priorities of the strategy is to reduce youth unemployment (European Commision 2010b). In the same year, the Commission released a communication that urged member states to participate in the youth guarantee initiative (hereinafter - YGI) (European Commision 2012a). In 2012, the European Commission proposed a package of different measures and instruments (European Commision 2012b). In The package was aimed towards helping member states to challenge youth unemployment by creating new education and work opportunities. The YGI aims to help all the youth that do not participate in the labor market by providing one with a job offer, opportunity for further studies or training. A young person that has lost his job or finished education should be provided with an offer within 4 months.

Due to differences of the number of young people in a NEET situation in member states, regions or the local level, the YGI program structure and ways of implementation can vary. For example, in Lithuania the YGI accommodates youths up to the age of 29. A member state must designate an organization that is responsible for the preparation of the initiative, management and co-ordination. Similarly, there is a focus on sustainable and inter-sectoral cooperation between different interest parties, i.e. the initiative focuses on creating cooperation between the educational sector, employers, employment services, career planning consultants, training institutions and youth support workers. This is so, given that sound cooperation is the best way to provide young people with employment opportunities (European Commision 2012a).

Further on, there is ongoing communication with youth and youth organizations in the hopes to further strengthen and develop the YGI (Council of the European Union 2013a). The adoption of a recommendation concerning YGI plan (hereinafter - the Plan) was approved by Lithuania on December 16 ${ }^{\text {th }}, 2013$ (Ministry of Social Security and Labour 2013a). Following the recommendations, the implementation of the plan is coordinated by the Ministry of Social Security and Labour (hereinafter - MSSL) which is responsible for forming, coordinating and controlling Lithuanian youth policy. Lithuanian Labour Exchange (hereinafter- LLE) and the Department of Youth Affairs (hereinafter-DYA), which are institutions under the MSSL became partners responsible for the plan's implementation. The boost for inter-institutional and cross-sectoral cooperation was provided on January $14^{\text {th }}, 2014$ when representatives from different sectors signed a memorandum of cooperation in regards to the implementation of YGI. On November $27^{\text {th }}, 2014$ plan for the implementation of YGI was renewed, however any additional institutions didn't show they big interest to join and jointly implement the YGI. Generally it stayed again only under the responsibility of MSSL and it subordinated institutions (LLE and DYA) (Ministry of Social Security and Labour 2014a).

The final approved plan put the MSSL and its subordinate institutions responsible for providing individuals that have fallen out of the education or labor systems with the YGI. LLE took responsibility to provide the youth guarantee to individuals that are registered as job seekers, through active labor market policies and vocational and career guidance services. The LLE become also responsible for long-term intensive help to unemployed and school drop-outs. It collaborates with NGO's to promote the integration of young people into the labor market and or the education system, social rehabilitation and preparation for employment in the labor market services. The DYA put a focus on individuals that are harder to reach and who are not registered in the LLE. In regards to the YGI, the DYA have created strong working network with youth policy coordinators (1 per municipality), youth organizations, youth centers and open youth spaces in order to identify and monitor young people in a NEET situation, providing them with social, educational, psychological and motivation services.

Network of 64 youth guarantee coordinators was created in Lithuania too. They were employed in the YGI project. The number arose from different needs and numbers of young people in a NEET situation per municipality. Up to now the youth guarantee coordinators are responsible for locating and identifying young people in a NEET situation. Similarly, they are responsible for gathering consent to participate in the project, providing Young people in a NEET situation with information about different opportunities and sending information to the DYA. Further on, the youth guarantee coordinators are responsible for making individual youth guarantee plans which may include mediation, help with self development, social and life skill growth, motivation, information, advisory mechanisms, volunteering possibilities and others. Youth guarantee coordinators estimate that by the time the program finishes, they will have had opportunity to work with over 12.000 young people in a NEET situation (Implementation of Youth Guarantee... 2017). It is important to note that the process included partners from the non-governmental sector. NGOs are important partners in overall youth policy and development work which is based on a cross-sectoral approach and systematic information sharing.

It is also important to note that the DYA is responsible for the national youth volunteering program. This program is carried out as an ESF project "Youth Voluntary Service", and it aims to enable young people to volunteer and to gain personal, social, professional skills and work experience, allowing them to choose a profession, re-integrate into 
the formal education system and (or) prepare to enter the labor market (Ministry of social Security and Labour 2013b). Volunteering in Lithuania is popular among young people; it is estimated that around 350 young people participate through Erasmus + and the national youth volunteering program every year.

When considering the impact of YGI and the overall effectiveness of locating young people in a NEET situation, one must understand the importance of municipal youth affairs coordinators. Even though, the municipal youth affairs coordinators are not officially part of the project, they provide very important inter-sectoral cooperation. Finally, it is important to note that, to ensure the proper implementation of the overall project in each territory there must be efficient and effective inter-agency cooperation between the municipal administration, the police, probation services and neighborhoods and so on.

The whole created structure of this system and the process of work can be viewed in Figure 3 provided below.

The youth guarantee initiative marks a new stage in the history of youth policy, that is; youth policy for the first time, through its different measures and actions influences labor issues in a constructive way. As mentioned previously in the article, it is important to note that coordinated measures coming from two different policy fields create a symbiotic initiative that works towards ensuring strategic governmental goals. Similarly, the actions arising from the two policy fields are planned together in order to ensure sound transition from one system to another, avoid duplicating funds, and to monitor results accordingly. The founding of the project steering group increased sound cooperation and included both-youth policy and employment policy actors.

Such close cooperation in the planning and implementation phases allows for close monitoring and coordination created for a mutual aim.

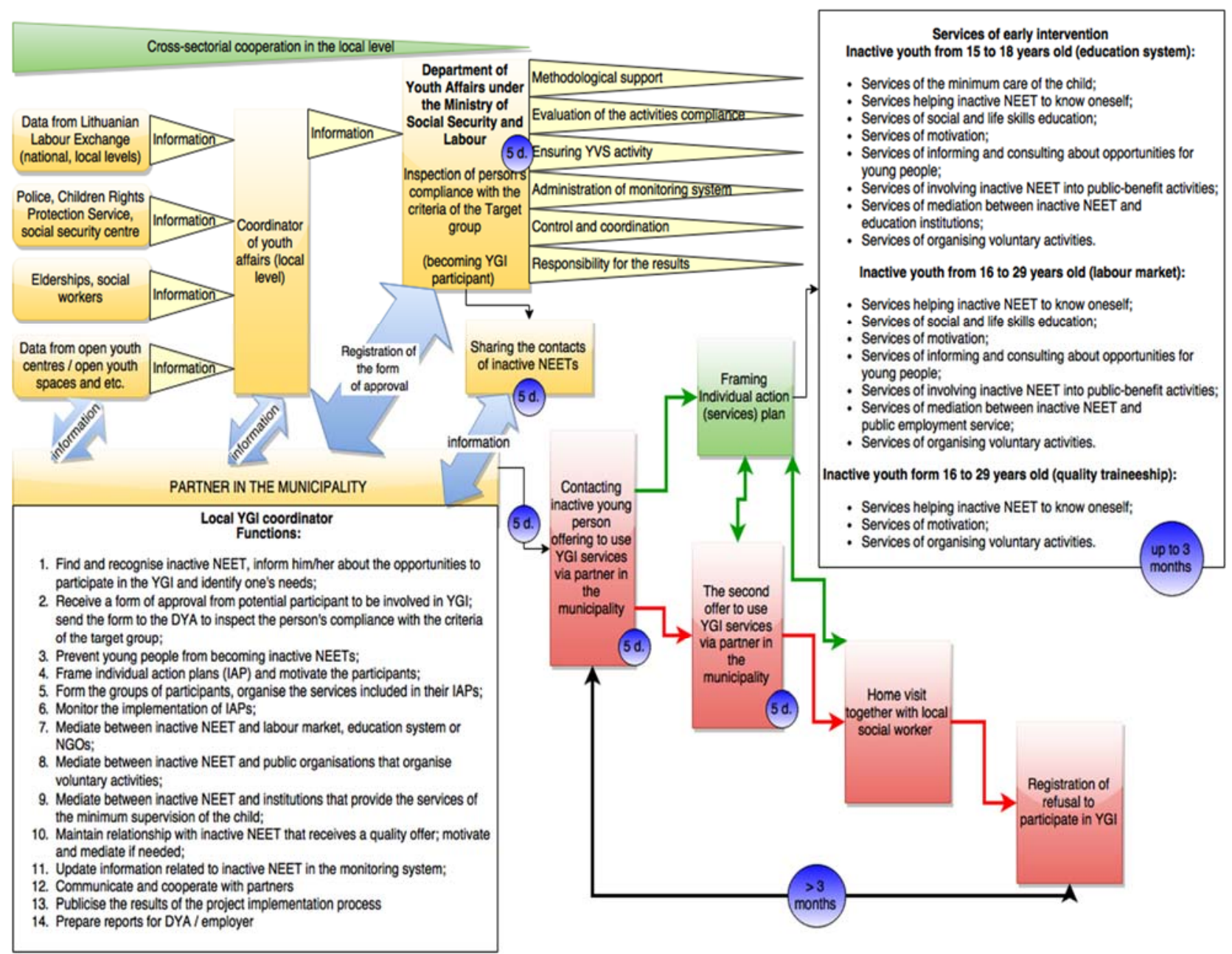

Fig. 3. Work process with persons in a NEET situation (Source: compilited by author's)

Even though the system has been created earlier, the DYA and its partners started concrete practical work with NEET youth on February $8^{\text {th }}, 2016$. Throughout 2016 , the complete number which both authorities have reached (including LLE and DYA measures) was 8709. 1266 were youths belonging to the previously mentioned inactive group (DYA working field/youth policy field). Of these 1,266 young people, 342 implemented the plan and received a high quality offer of employment, training or work placement / internship; 642 persons have implemented the plan but did not receive a high quality proposal; 127 persons ended participation in YGI before the plan was made; 155 persons 
ended their participation before implementation of the plan. It is important to note that, in order to ensure continuity within national youth volunteering program and use this program's tool as a measures in the plan of YGI, measures from this program have been integrated into YGI plan in the 2016. The integration was pursued due to the attractiveness of the voluntary program and its results. From February $7^{\text {th }}, 2014$ to October $30^{\text {th }}, 2015$ the national youth volunteering program managed to include $\mathbf{6 8 9}$ volunteers. 634 young people concluded the volunteering program successfully. Out of 689 participants, 171 found employment, 65 returned or planned to return back into the education system and 20 emigrated. During this period, 323 host organizations received accreditation. When volunteering was incorporated into the YGI program, 115 new host organizations received accreditation by the end of 2016.

The voluntary activities within the YGI program involved 277 young inactive people and 183 young people registered at the labor exchange. Within a relatively short period of implementation, the figures demonstrated good results. When looking at the youth guarantee initiative, one can see that most measures that were taken came from the youth policy field. The measures arising from youth policy can be regarded as primary prevention measures. (See. Example below)

\section{Primary intervention:}

- Development of additional skills and competencies

- Psychological and social rehabilitation measures

- Volunteering

- Basic child care

- Help in knowing yourself

-Development of social and life skills

- Motivation

- Information and advice about different available opportunities

- Mediation and advice in regards to educational institutions

- Inclusion into activities that benefit the public

- Help with organizing voluntary activities

Secondary intervention:

- Vocational training

- Job skills acquisition support

- Employment subsidies

The given examples illustrate the notion that youth policy and its measures, are effective enough to contribute to other strategic objectives such as, the reduction of youth unemployment - part of strategic employment policy that is not directly associated with youth policy. They also illustrate that when effective planning and coordination is used, one can expect smooth process and good results. In addition, the effectiveness can be measured by the fact that, 1266 were young people in a NEET situation from the youth policy sector and with effective common youth and employment policies work the strategic goal can be reached much faster. This is important because inactive youths represent a part of group that can prove to be challenging to work with. The inactive youths do not voluntarily seek help from different agencies; they are in need of motivation and help. Only after help and motivation is provided, inactive youths can be ready for integration and or reintegration into the education system and the labor market. Given this, one can say that youth policy adds to the solution of possible mistakes made earlier by the education system.

\section{Conclusions}

Analysing implementation of YGI has shown that it is clear that the implementation of these measures should be continued further. However, for the project and the system in general to be an overall success, and for further good cooperation between the employment and youth policies there is a continuing need to evaluate arising challenges and factors that might impede the process. Some of the challenges and hindering factors that need to be continuously dealt with are mentioned below were identified and are presented in the article:

Lack of outreach youth work in Lithuania. It is difficult to reach young people that live in secluded areas and are not able to travel to where the services are provided. Similarly, outreach youth work would further social integration of disabled youths. The issue arises from the fact that youth workers need further knowledge and experience in working with young people in a NEET situation. Finally, this kind of youth work up to today is still not legally regulated nationally.

Issues with the local level/lack of attention at the local level. Weak municipal contribution to the implementation of YGI. YGI implementation in many municipalieties it is still not hight on the agenda of youth issues, however it is clear that best results are achieved when there is a strong cross-sectoral cooperation at the local level and that national measures on their own are not sufficient. Cooperation of public, private and NGO sectors it is success factor for reaching the best result, nevertheless this partnership it is weak in many municipalities. 
Time issues. Working with young people in a NEET situation can be challenging, especially when results are expected within 4 months. Research has shown that this target needs more time and more individual attention, having this in mind further recommendation would be to increase the time of work up to 6 months. It should be taken into account while drafting measures for NEET both on European and national levels.

The education sector. There is a weak engagement coming from the education sector when working with young people in a NEET situation. At times there is a lack of cooperation between youth policy and education policy sectors. A strong link between the two would help solve such issues as the occurrence of drop-outs and assist the process of reintegration into the education system.

One of the ways to deal with such issues is to analyze and correctly adapt best practices coming from different EU member states. While writing this article many of different models linked to the work with NEET were analysed. Best practices example from the EU countries which could be taken as basis for creating detached youth work could be examples from Germany, Luxembourg, Sweden, United Kingdom, Finland.

Germany can be used as a good practices example due to the good level of outreach work. In Germany, outreach youth workers work in streets, stations and large youth gathering places. They also work with different institutions and provide mediation help. Luxembourg has over 10 years of experience with youth work. Youth work is implemented mostly by the local authorities and have a strong focus on school drop-outs. Youth workers have established sound cooperation with institutions coming from the education sector. When a young person drops out of school, a youth worker is notified. After this, he is able to work with the young person in a constructive manner in order to find a solution. If the young person does not wish to come back to school, the youth worker might help with writing up CVs, cover letters, motivational letters etc. Similarly, in order to develop social skills of young people in need the youth worker might present other options, such as group lessons and lectures or participating in the youth guarantee initiative. In Sweden, the national level is responsible for employment policy and the labor market. However, the local level must be informed about all young people in a NEET situation up to the age of 20 and is also responsible for providing services and taking care of the individuals. United Kingdom can be used as a good example due to their longstanding practice with detached youth work. Organizations that practice detached youth work are able to provide social services to young people with disabilities, social exclusion in to those that are prone to commit criminal offences. In Finland, outreach youth work and work with street youths is regulated nationally towards early school drop outs and young people in a NEET situation up to the age of 29. The work is done on the local level. Finland has well developed interagency and inter-sectoral experience that places great emphasis on multidisciplinary cooperation. The cooperation includes youth workers, social workers, health care professionals, the probation service and others and covers 90 percent of all municipalities (European Commission 2012c; European Commission 2015b).

\section{Recommendations for youth work improvement in Lithuania and the implementation of the youth guarantee}

The analysis of legal acts, YGI implementation system, youth work system in Lithuania has shown that prompt actions in the field of youth policy needs to be taken. In order to have strong youth policy and strong cross-sectorial cooperation with other sectors these steps must be done:

- Revision, preparation and adoption of Youth Policy Framework Act No. IX-1871 (Official Gazette 2003, No. 119-5406), where youth work and it working methods should be clearly described must be done as soon as possible

- Concept of youth work system must be created and approved by by the order of the Minister of the MSLL;

- Outreach youth work must be further developed in order to reach youths that live in remote areas, are disabled, sufficient resources from the state should be provided

- Cooperation with education sector must be improved. This is especially important if the system wants to reach early drop-outs.

\section{References}

Baranowska, A.; Gebel, M. 2010. The determinants of youth temporary employment in the enlarged Europe, European Societies 12(3): 367-390. https://doi.org/10.1080/14616690903165434

Christopoulou, R. 2013. Why Have labour market outcomes of youth in advanced economies deteriorated? Journal of Economic Analysis \& Policy 13(1): 203-237. https://doi.org/10.1515/bejeap-2012-0002

Council Conlusions. 2013b. On enhancing the social inclusion of young people not employment, education or training [online], [cited 27 February 2017]. Available from Internet: http://eur-lex.europa.eu/legal-content/EN/TXT/?uri=CELEX\%3A52014XG0201(02)

Council of the European Union. 2013a. Recommendation on Youth Guarantee initiative setting [online], [cited 27 February 2017]. Available from Internet: http://eurlex.europa.eu/legal-content/EN/ALL/?uri=CELEX\%3A32013H0426(01)

Cuesta, M. B.; Heras, R. L.; Carcedo, J. M. 2011. Minimum wage and youth employment rates, Revista De Economica Aplicada 19(56): $35-57$. 
Cunningham, W. V.; Villasenor, P. 2016. Employer voices, employer demands, and implications for public skills development policy connecting the labor and education sectors, World Bank Research Observer 31(1):102-134. https://doi.org/10.1093/wbro/lkv019

European Commission Report. 2012c. Youth Employment European good practice projects. Luxembourg: Publications Office of the European Union. 82 p. ISBN: 978-92-79-21215-4.

European Commission Report. 2014. Working with young people: the value of youth work in the European Union [online], [cited 7 March 2017]. Available from Internet: http://ec.europa.eu/assets/eac/youth/library/study/youth-work-report_en.pdf

European Commission Report. 2015a. Quality youth work. A common framework for the further development of youth work [online], [cited 25 March 2017]. Available from Internet: http://ec.europa.eu/assets/eac/youth/library/reports/quality-youthwork_en.pdf

European Commission. 2010a. DG employment, social affairs and inclusion. Youth neither in employment nor education and training (NEET). Presentation of data for the 27 Member States“.

European Commission. 2010b. Youth on the move, a Europe 2020 initiative [online], [cited 27 March 2017]. Available from Internet: http://ec.europa.eu/youthonthemove/index_en.htm

European Commission. 2012a. Council Recommendation on establishing a youth guarantee [online], [cited 29 March 2017]. Available from Internet: http://eur-lex.europa.eu/legal-content/EN/TXT/?uri=CELEX\%3A52016DC0646

European Commission. 2012b. Employment, social affairs \& inclusion. Youth employment: Commission proposes package of measures [online], [cited 05 April 2017]. Available from Internet: http://ec.europa.eu/social/main.jsp?langId=en\&catId=1036\&newsId=1731\&furtherNews=yes

European Commission. 2015b. PES practices for the outreach and activation of NEETs. Brussels.

European Foundation for the Improvement of Living and Working Conditions. 2012a. NEETs - Young people not in employment, education or training: characteristics, costs and policy responses in Europe. Luxembourg: Publications Office of the European Union.

European Foundation for the Improvement of Living and Working Conditions. 2012b. Recent policy developments related to those not in employment, education and training (NEET) [online], [cited 07/ April 2017]. Available from Internet https://www.eurofound.europa.eu/observatories/emcc/comparative-information/recent-policy-developments-related-to-those-not-in-employment-education-and-training-neets

European Foundation for the Improvement of Living and Working Conditions. 2014. Mapping youth transition in Europe [online], [cited 03 April 2017]. Available from Internet: https://www.eurofound.europa.eu/publications/report/2014/labour-market/mapping-youth-transitions-in-europe

European Foundation for the Improvement of Living and Working Conditions. 2016a. Exploring the diversity of NEETs [online], [cited 07 April /2017]. Available from Internet:

http://ec.europa.eu/social/main.jsp?langId=en\&catId=1036\&newsId=1731\&furtherNews=yes

Eurostat database [online], 2017 [cited 27/02/2017; 25/03/2017; 31/03/2017; 07/04/2017]. Avaible from Internet: http://ec.europa.eu/eurostat/data/database

Graham, J. R.; Shier, M. L.; Eisenstat, M. 2014. Misalignment between post-secondary education demand and labour market supply: Preliminary insight from young adults on the evolving school to work transition, International Journal for Educational and Vocational Quidance 14(2): 199-219. https://doi.org/10.1007/s10775-014-9267-1

Hallsten, M.; Edling, C.; Rydgren, J. 2017. Social capital, friendship networks, and youth unemployment, Social Science Research 61: 234-250. https://doi.org/10.1016/j.ssresearch.2016.06.017

Implementation of youth guarantee initiative in Lithuania [online], 2017 [cited 07 April 2017]. Avaible from Internet: https://www.jaunimogarantijos.lt/en/

Junankar, P. N. 2015. The impact of the global financial crisis on youth unemployment, Economic and Labour Relations Review 26(2): 191-217. https://doi.org/10.1177/1035304615580536

Korpysa, J. 2010. Unemployment as a main determinant of entrepreneurship, Transformation in Business \& Economics 9(1):109123.

Law on youth policy framework of the Republic of Lithuania (Official Gazette), 2003, No. 119-5406; 2005, No. 144-5238; 2016, TAR 2016-11-17, i. k. 2016-26979.

Ministry of Social Security and Labour Minister. 2013a. Youth Guarantee initiative plan aproved by order of the Minister of Social Security and Labour No. A1-692 of 16 December 2013.

Ministry of Social Security and Labour Minister. 2013b. The National Youth Volunteering Program approval order No. A1-73 February $25^{\text {th }}, 2013$.

Ministry of Social Security and Labour Minister. 2014a. Youth Guarantee Initiative Plan order No. A1-584 regarding the change of Lithuanian Ministry of Social Security and Labour Minister order No. A1-692 on Youth Guarantee initiative Plan Approval December $16^{\text {th }} 2013$.

Statistics Lithuania database [online], 2017 [cited 27/01/2017; 17/02/2017; 25/02/2017; 29/03/2017; 31/03/2017; 07/04/2017]. Avaible from Internet: http://osp.stat.gov.lt/en/web/guest/home

Tosun, J. 2017. Promoting youth unemployment through multi-organizational governance, Public Money \& Management 37(1): 39-46. https://doi.org/10.1080/09540962.2016.1249230

Turek, D. 2015. Competencies of young people on the labour market - employers' expectations, E-mentor 3: 8-16. https://doi.org/10.15219/em60.1179 